Article

\title{
Spatial-Temporal Evolution and Driving Factors of Green Building Development in China
}

\author{
Yi Gao *, Gaosheng Yang and Qiuhao Xie
}

Institute of Engineering Management, Hohai University, Nanjing 211100, China; ygshh@hhu.edu.cn (G.Y.); xieqiuhao@hhu.edu.cn (Q.X.)

* Correspondence: gaoyi329@163.com

Received: 2 March 2020; Accepted: 29 March 2020; Published: 1 April 2020

\begin{abstract}
With the development of the world economy and the rapid increase in population, the carbon dioxide produced by large energy consumption has made environmental issues increasingly prominent, which has brought severe challenges to the survival and development of human society. The construction industry, as a major energy consumer and emitter, must change. Green buildings are an important way to promote the concept of sustainable development in the construction industry. In order to deepen the understanding of the spatial-temporal distribution and evolution characteristics of China's green building development, this study collected statistical data of China's green building label projects from 2008 to 2018, and studied the development status of China's green buildings in three aspects: equilibrium, spatial distribution characteristics and spatial correlation. In addition, the driving factors of green buildings development were analyzed by using geological detectors. The results show that: (1) China's green building development level has a high spatial imbalance and obvious agglomeration situation, but there is a large diffusion effect; (2) the spatial distribution characteristics, such as the distribution center, distribution range, distribution direction, and distribution shape of green buildings are constantly changing, and the changes have regularity; (3) in the early stage of green building development, there was a significant positive correlation, but most provinces were in low-low clusters; (4) economic level, technical level, and education level are the main factors influencing the development of green buildings.
\end{abstract}

Keywords: green buildings; spatial-temporal pattern; evolution characteristics; driving factors

\section{Introduction}

With the emergence of energy crises and environmental issues worldwide, issues such as population explosion, resource depletion, environmental pollution, and climate warming have become the focus of attention. Many countries have begun to focus on low energy consumption industries. In order to find new energy sources and also take into account environmental pollution issues, many countries have begun to reduce the use of non-renewable energy sources and reduce carbon dioxide emissions as much as possible. Considering the problem of environmental pollution, many countries have begun to reduce the use of non-renewable energy and reduce carbon dioxide emissions as much as possible. The United Nations released the "United Nations Framezwork Convention on Climate Change" in 1992. "The Paris Agreement" was officially adopted in 2016, and countries around the world have joined the protection of the environment. According to the IPCC's (Intergovernmental Panel on Climate Change) fourth assessment report, the construction industry is the industry with the largest energy consumption in the world, and the amount of carbon dioxide emitted by construction activities accounts for about $36 \%$ of worldwide emissions [1]. It can be found from this data that the construction industry has become one of the industries with the largest carbon emissions and energy consumption in the world, and the promotion of green buildings should be put on the agenda. Sangtae No et al. [2] 
compared the energy consumption of non-certified general buildings with certified buildings, and the results showed that Green Standard for Energy and Environmental Design (G-SEED)-certified buildings use at least 35.5-48.9\% less energy than non-certified buildings. According to the prediction of the World Bank, half of the new buildings in the world will be produced in China between 2005-2020, which shows that it is of great significance to carry out green building construction in China.

Green buildings are defined as buildings that maximize resource conservation (energy saving, land saving, water saving, material saving), protect the environment, reduce pollution, provide people with healthy, applicable, and efficient spaces and coexist in harmony with nature during their entire life [3]. Developing green buildings is an important part of China's sustainable development strategy, and it is an important way for the construction industry to save resources, reduce pollution, reduce energy consumption, and achieve sustainable development. By the end of 2018, China's urban green buildings area has totaled more than 2.5 billion square meters, and green buildings accounted for more than $40 \%$ of new urban civil buildings. As a new type of technological innovation product, green building should show a certain spatial-temporal distribution and evolution law during its large-scale development process [4]. By studying the spatial distribution characteristics and temporal development law of green buildings in China, the results can guide the formulation of green building planning policies and promote the innovative management model of green buildings. In addition, it is of great significance to improve the theory of eco-city development, spatial planning, and urban green innovation.

Globally, the research on green buildings mainly focuses on the green building evaluation system [5], policies and regulations [6], incentive measures [7], technology research and development [8], and risk management [9]. Kats et al. [10] analyzed the input costs of 33 green buildings in California, and started the trend of cost analysis of green buildings. Fuerst et al. [11] conducted a cost-benefit study of 24,479 office buildings in the United States, and concluded that green buildings can achieve higher rent levels and lower vacancy rates than traditional buildings. Tollin [12] examined the design, construction, ownership, and operational risks of green buildings and provided some solutions to the problems. Zou et al. [13] believed that green buildings bring new business development opportunities and significant risks to the construction supply chain, and education and training, supply chain cooperation, knowledge and information sharing, experience accumulation, and technology application can improve the performance of green buildings. Madew et al. [14] described the process of using green building assessment tools to evaluate green buildings in Australia. Švajlenka did some research on the sustainability of building materials. He analyzed industrial buildings in the V4 countries (Czech Republic, Slovak Republic, Poland, and Hungary-Central Europe), and pointed to the benefits of modern wood-based construction systems compared to traditional materials (concrete and steel) [15]. He also presented an evaluation method of the efficiency and sustainability of timber-based buildings, based on analyses of socio-economic research and theoretical assumptions [16].

Recently, research on the spatial-temporal characteristics of green buildings has attracted attention globally. Most of these studies have found that the geographical distribution of green building presents certain differences and clustering characteristics [17,18]. Kaza et al. [19] used the local Moran's I, trends in the nearest neighbor distances (NND) and nearest neighbor indices (NNI), and scanned statistics to analyze the spatiotemporal agglomeration characteristics of green buildings in the United States. Cidell [20] collected data on LEED (Leadership in Energy and Environmental Design) certified buildings and professionals in the United States and studied their geographic distribution and spread. Fuers et al. [21] and Kahn et al. [22] also studied the spatial distribution of green buildings in the United States and California, respectively.

However, the current research results on the distribution and evolution characteristics of green buildings in China are very limited. Some studies used non-spatial time-series statistical methods that lacked a spatial perspective [23], and the data used were section data or panel data with a small time span [24]. Those studies are difficult to use for revealing the spatial-temporal pattern and evolution of 
green buildings in China, and the quantitative research using geographic information technology and spatial statistical methods is insufficient.

In terms of driving factors for green building development, scholars from Germany [25], Singapore [26], Malaysia [27], Canada [28], Greece [29], and other countries have studied the driving factors of green buildings in their country. In addition, some scholars used structural equation models and evolutionary game models to study the driving mechanism of green buildings from the demand side, the supply side, and the government side. On the demand side, Zhang analyzed the influencing factors of Chinese youth's willingness to purchase green housing through questionnaires and structural equation models, and concluded that government incentives are the most important determinants [30]. Maichum interviewed Thai employees with a high school education or higher, and used structural equation models to study the influencing factors of willingness to consume green products. It was found that consumer attitudes, subjective norms, and perceived behavior control had significant positive effects [31]. On the supply side, Yang et al. [32] used questionnaire surveys and structural equation models to analyze developers' willingness to develop green buildings based on the planned behavior theory. The research results showed that subjective norms and perceived behavior control factors had significant effects. Delmas et al. [33] proposed that external pressure from stakeholders (government, consumers, competitors, social environmental groups, etc.) on enterprises would cause companies to comply with green management strategies, and empirically concluded that external mandatory policies would cause companies to comply with green management. Sarkis et al. [34] also reached the same conclusion through an empirical study of the Spanish construction industry. Henriques et al. [35] believed that attitudes towards the environment, environmental pressure, enterprise size, and industry rules are the most likely influencing factors for companies to develop their development plans. On the government side, Diana et al. [36] believed that the driving factors that promote the development of the green building market were divided into four aspects: macro-control mechanisms, micro-market instruments, government financial incentives, and information disclosure. Karkanias et al. [37] researched the green building market in Greece and found that insufficient policy incentives, insufficient basic information, and unstable policy environment were important reasons affecting the implementation of government incentive policies, and insufficient policy implementation had also hindered the promotion of green buildings. Jim [38] pointed out that in terms of promoting policies, policy makers should communicate effectively with policy managers and implementers, and focus on transforming theory into practice. GeoDetector is widely used in the natural and social fields to detect the driving factors of various spatial differentiation phenomena and their interactions, and has achieved good results, such as urban structure, health risks, house prices, employment, crime areas, etc. It has two obvious advantages: on the one hand, it can analyze both quantitative and qualitative data, and on the other hand, it can explore the interaction of influencing factors. Therefore, this study used the GeoDetector model to detect the effect intensity and regional differences of the factors affecting the development of green buildings in China.

This study collected data on green building label projects in 31 provinces in China from 2008 to 2018 (based on the availability of data, Hong Kong, Macao, and Taiwan did not do research). With the technical support of ArcGIS and Stata software, the regional difference indexes, standard deviation ellipse method, and spatial autocorrelation method were used to study the spatial-temporal evolution of China's green building development from three aspects: spatial equilibrium, spatial distribution, and spatial correlation. Moreover, this study established an index system of driving factors for green building development from three aspects: government regulation measures, public purchasing attitudes, and economic and technological environment; it then used GeoDetector to analyze the driving factors of green building development. The study can provide an empirical basis for the country and provinces to make scientific decisions, and it is of reference value for formulating green building policies and innovative management models.

Based on the above analysis and the state of green buildings in China, the following hypotheses are proposed: 
Hypothesis 1 (H1). The spatial equilibrium of China's green building development is gradually increasing.

With the popularization of the concept of green sustainable development, all provinces of China have paid more and more attention to green buildings and adopted a series of measures to promote the development of the green building industry. The development gaps between provinces should continue to decrease.

Hypothesis 2 (H2). The spatial distribution characteristics of green buildings in China are constantly changing, and the changes are regular.

With the development of China's green buildings, affected by factors such as economic level, technical conditions, and government control measures, the spatial distribution characteristics of green buildings, including the distribution center, distribution range, distribution direction, and distribution shape should be constantly changing. In addition, the changes should be stable and regular, rather than random.

Hypothesis 3 (H3). China's green building development has a positive spatial correlation.

Because green building is a new technology product, its expansion depends on the support of economic and technological conditions, rather than random distribution. Regional green building levels will be affected by neighboring areas or areas with similar economic levels. The spatial correlation may be due to knowledge spillovers between regions, human capital flows, transportation, etc.

Hypothesis 4 (H4). The development of green buildings is affected by government regulation measures, public purchasing attitude, and the economic and technological environment, and there are interactions between factors.

Based on the theory of planned behavior, real estate developers building green buildings are affected by economic and technological conditions, government mandatory policies, economic incentives, and consumer purchase intention. Each factor does not work alone; they may interact through mutual cooperation.

\section{Indexes and Methods}

\subsection{Indexes}

(1) Green Building Development Indicator

The research on green buildings has become a hot topic in the world. Europe, the United States, Japan, and other regions and countries have proposed concepts such as green buildings, sustainable buildings, and ecological buildings. Subsequently, green building assessment systems adapted to the national conditions of various countries have been formulated, including BREEAM (Building Research Establishment Environmental Assessment Method) in the United Kingdom, LEED in the United States, GBTOOL (Green Building Tool) in Canada, CASBEE (Comprehensive Assessment System for Building Environmental Efficiency) in Japan, etc. [39]. China promulgated the "Assessment standard for green building" in 2006, and the following year issued the "Evaluation technical details for green building (for Trial Implementation)" and "Measures for the administration of green building evaluation marks", gradually improving the green building evaluation system suitable for China's national conditions. Green building label projects are green buildings that receive a certain score in the green building evaluation, and the evaluation system includes six categories: land saving and outdoor environment, energy saving and energy use, water conservation and water use, material saving and material resource utilization, indoor environmental quality and operational management (residential building), and comprehensive life cycle performance (public buildings). 
Since 2008, the Ministry of Housing and Urban-Rural Development of China has organized the evaluation of green building label projects. By the end of 2018, 10,139 projects had obtained green building evaluation labels. This study takes the projects that have been awarded the green building label in China (excluding the Hong Kong, Macao, and Taiwan regions) from 2008 to 2018 as the research objects. Some quantitative research on green buildings selected the number of green buildings as the statistical analysis object [40,41], but it cannot rule out the impact of the scale of the local construction industry on green buildings. Therefore, the study calculated the ratio of the area of green building label projects in each province to the area of new construction to represent the level of green building development each year. The next step was to obtain the area of green building label projects from the announcements issued by the Ministry of Housing and Urban-Rural Development and statistical reports of the Department of Building Energy Efficiency and Technology. Then, the statistics of new construction areas were taken from China Statistical Yearbook (2009-2019).

(2) Indicator System of Driving Factors for Green Building Development

In recent years, scholars have done some analysis and research on the factors affecting the development of green buildings. Based on a theoretical analysis and a literature summary, this paper constructs a system of driving factors for the development of green buildings from three aspects: government regulation measures, public purchasing attitude, and economic and technological environment (Table 1).

(1) Government Regulation Measures

The economic externalities of green buildings lead to market failures; thus the government's macro-control has an important role in the development of green buildings. The "carrot + stick" type of regulation is the basic means for the government to regulate the market. Therefore, this paper studies the impact of government regulation on green buildings from two aspects: regulations (RE) and incentives (INC) [42]. Further, the regulations select green building-related regulations formulated by each province, including local laws and rules, government regulations, normative documents, working papers, etc., and incentives are measured by whether to implement financial subsidies and plot ratio rewards for green buildings in each province [43].

(2) Public Purchasing Attitude

The enthusiasm of real estate companies for developing green buildings relies heavily on consumer demand for green buildings, and the demand for green buildings depends on consumers' environmental awareness, social values, social responsibility, awareness and acceptance of green buildings, etc. [44]. Therefore, this paper selects the Baidu index (BD) and education level (EDU) to measure public purchasing attitude. Among them, the Baidu index is the proportion of users paying attention to green buildings to commercial housing, and the education level was calculated using the formula of education level per capita of Yijun, Y. [45].

(3) Economic and Technological Environment

Economic level (GDP) is an important factor affecting the development of green buildings. Economic growth will drive the development of the construction industry, which will bring market opportunities for green buildings. This paper uses the GDP per capita to represent the regional economic level. Technology (TEC) is an important support for the development of green buildings. The maturity of green building technology, the development of green building materials, the improvement of green design and construction technology, and the improvement of the assessment and certification system have changed green buildings from ideas to entities [46]. This article selects the ratio of R\&D internal expenditure to GDP to measure the regional technology level, and whether to formulate green building design standards to measure the green building technology level, and then adds the two indicators after standardization. 
Table 1. Indicator system of driving factors for green building development.

\begin{tabular}{|c|c|c|c|}
\hline Drivers & Factors & Definition & Data Sources \\
\hline \multirow{3}{*}{$\begin{array}{l}\text { Government Regulation } \\
\text { Measures }\end{array}$} & Regulations (RE) & $\begin{array}{l}\text { Number of green building-related } \\
\text { regulations }\end{array}$ & $\begin{array}{l}\text { Peking university magic } \\
\text { weapon website }\end{array}$ \\
\hline & & Whether to implement green & Provincial housing and \\
\hline & Incentives (INC) & $\begin{array}{l}\text { building financial subsidies and plot } \\
\text { ratio incentive policies }\end{array}$ & $\begin{array}{l}\text { construction bureau } \\
\text { website }\end{array}$ \\
\hline \multirow{4}{*}{$\begin{array}{l}\text { Public Purchasing } \\
\text { Attitude }\end{array}$} & Baidu Index (BD) & $\begin{array}{l}\text { The proportion of users paying } \\
\text { attention to green buildings to } \\
\text { commercial housing }\end{array}$ & Baidu index website \\
\hline & & $\mathrm{EDU}_{\mathrm{i}}=\mathrm{P}_{\mathrm{i} 1} \times 6+\mathrm{P}_{\mathrm{i} 2} \times 9+\mathrm{P}_{\mathrm{i} 3} \times 12+$ & \\
\hline & & & China statistical \\
\hline & Education Level (EDU) & $\begin{array}{l}\text { whose education background is } \\
\text { elementary, junior high, high, } \\
\text { tertiary, and above, respectively. }\end{array}$ & yearbook \\
\hline \multirow[t]{2}{*}{$\begin{array}{l}\text { Economic and } \\
\text { Technological } \\
\text { Environment }\end{array}$} & Technical Level (TEC) & $\begin{array}{l}\text { R\&D internal expenditure/GDP; } \\
\text { Whether to set green building } \\
\text { design standards }\end{array}$ & $\begin{array}{c}\text { China statistical } \\
\text { yearbook; Provincial } \\
\text { housing and construction } \\
\text { bureau website }\end{array}$ \\
\hline & Economic Level (GDP) & GDP per capita indicator & $\begin{array}{c}\text { China statistical } \\
\text { yearbook }\end{array}$ \\
\hline
\end{tabular}

\subsection{Methods}

\subsubsection{Spatial Equilibrium}

(1) Overall Spatial Equilibrium

(1) The coefficient of variation (CV) of green building development is the ratio of the standard deviation and the average value of green building development in each province. The smaller the coefficient of variation, the higher the spatial equilibrium of green building development in China. The calculation formula is the following:

$$
C V=\sqrt{\sum_{i=1}^{N}\left(x_{i}-\bar{x}\right)^{2} / N / \bar{x}}
$$

where $\mathrm{N}$ is the number of samples; $x_{i}$ is the level of green building development in province $i$, which is represented by the ratio of the area of green building label projects to the area of new construction; and $\bar{x}$ is the sample average.

(2) The green building concentration $\left(C R_{n}\right)$ measures the concentration of green building development, which is the share of the top $n$ provinces with a high level of green building development in the total value. A high $C R_{n}$ value indicates a high concentration of green building development in China. It is calculated by the expression as follows:

$$
C R_{n}=\frac{\sum\left(x_{i}\right)_{n}}{\sum\left(x_{i}\right)_{N}}
$$

(3) The green building spatial Gini coefficient $(G)$ compares the scale of green building construction with the scale of housing construction, which measures the aggregation degree of green building across the country. The larger the Gini coefficient, the higher the aggregation degree of green buildings; otherwise, the aggregation degree is lower. The formula is as follows:

$$
G=\sqrt{\sum_{i=1}^{n}\left(S_{i}-X_{i}\right)^{2}}
$$


Here, $S_{i}$ represents the proportion of province $i$ in the national green building label projects area, and $X_{i}$ represents the proportion of province $i$ in the national new construction area.

(2) Local Spatial Equilibrium

The local spatial equilibrium of green building development is measured by the location entropy (Q). $Q_{i}>1$ indicates that the green building development in province $i$ is higher than the national average and has agglomeration; $Q_{i}<1$ means lower than the national average. The location entropy $(Q)$ is defined as follows:

$$
Q_{i}=S_{i} / X_{i}
$$

\subsubsection{Spatial Distribution Characteristics}

The standard deviation ellipse method (SDE) is a classic method for analyzing spatial distribution characteristics. With the help of ArcGIS software, we calculated parameters such as ellipse center coordinates, ellipse area, rotation angles, and major and minor axes standard deviation, which can be used to explain the centrality, distribution range, directionality, and spatial shape of green building development. The parameters' calculation formulas are as follows:

$$
\begin{aligned}
\text { Certer of gravity : } M(a, b)=\left[\left(\sum_{i=1}^{N} \omega_{i} a_{i} / \sum_{i=1}^{N} \omega_{i}\right),\left(\sum_{i=1}^{N} \omega_{i} b_{i} / \sum_{i=1}^{N} \omega_{i}\right)\right] \\
\text { Rotation angles : } \tan \theta=\frac{\left(\sum_{i=1}^{N} \omega_{i}{ }^{2} \tilde{a}_{i}{ }^{2}-\sum_{i=1}^{N} \omega_{i}{ }^{2} \tilde{b}_{i}{ }^{2}\right)+\sqrt{\left(\sum_{i=1}^{N} \omega_{i}{ }^{2} \tilde{a}_{i}{ }^{2}-\sum_{i=1}^{N} \omega_{i}{ }^{2} \tilde{b}_{i}{ }^{2}\right)+4 \sum_{i=1}^{N} \omega_{i}{ }^{2} \tilde{a}_{i}{ }^{2} \tilde{b}_{i}{ }^{2}}}{2 \sum_{i=1}^{N} \omega_{i}{ }^{2} \tilde{a}_{i}{ }^{2} \tilde{b}_{i}{ }^{2}} \\
\text { Major Axes Standard Deviation }: \sigma_{x}=\sqrt{\frac{\sum_{i=1}^{N}\left(\omega_{i} \tilde{a}_{i} \cos \theta-\omega_{i} \tilde{b}_{i} \sin \theta\right)^{2}}{\sum_{i=1}^{N} \omega_{i}{ }^{2}}} \\
\text { Minor Axes Standard Deviation }: \sigma_{y}=\sqrt{\frac{\sum_{i=1}^{N}\left(\omega_{i} \tilde{a}_{i} \sin \theta-\omega_{i} \tilde{b}_{i} \cos \theta\right)^{2}}{\sum_{i=1}^{N} \omega_{i}^{2}}}
\end{aligned}
$$

where $a_{i}, b_{i}$ are the center coordinates of province $i, \omega_{i}$ is the weight of green building development level in province $i$, and $\tilde{a}_{i}, \tilde{b}_{i}$ is the coordinate deviation from the center coordinate of province $i$ to the ellipse's.

\subsubsection{Spatial Correlation}

(1) Global Spatial Correlation

This paper analyzes the global spatial correlation of green buildings by calculating the global Moran's index, which is defined as follows:

$$
\begin{gathered}
I=\frac{\sum_{i=1}^{N} \sum_{j=1}^{N} W_{i j}\left(\omega_{i}-\bar{\omega}\right)\left(\omega_{j}-\bar{\omega}\right)}{S^{2} \sum_{i=1}^{N} \sum_{j=1}^{N} W_{i j}} \\
S^{2}=\frac{1}{N} \sum_{i=1}^{N}\left(\omega_{i}-\bar{\omega}\right), \bar{\omega}=\frac{1}{N} \sum_{i=1}^{N} \omega_{i}
\end{gathered}
$$


where $W_{i j}$ represents the spatial weight matrix; this paper uses an adjacency matrix and an economic distance matrix to study the spatial effects of neighboring provinces and regions with similar economic development levels. The adjacency weight is represented by a binary matrix, and economic distance weights use the average GDP per capita from 2008 to 2018.

(2) Local Spatial Correlation

The global Moran's index reflects the spatial correlation of green buildings across the country, while the local Moran's index reflects the spatial correlation between each province and other regions according to the weight matrix:

$$
I_{i}=\frac{\left(\omega_{i}-\bar{\omega}\right)}{S^{2}} \sum_{j=1}^{N} W_{i j}\left(\omega_{j}-\bar{\omega}\right)
$$

\subsubsection{Driving Factors}

GeoDetector is used to analyze the laws of geospatial differentiation and to detect internal and external factors. It contains four detectors, including a factor detector, which detects the explanatory power of the independent variable to the dependent variable; an interaction detector, which identifies the interactions between different factors; a risk detector, which is used to determine whether there are significant differences in feature attributes between two regions; and an ecological detector, which is used to compare the effects of the two independent variables on the spatial distribution of the dependent variable. The calculation formula is the following:

$$
q=1-\frac{1}{n \sigma^{2}} \sum_{i=1}^{L} n_{i} \sigma_{i}^{2}
$$

In the formula, $q$ is the interpretation degree of detection factors to the spatial differentiation of dependent variables, and a larger $q$ indicates a greater influence of the factor on the spatial differentiation of green buildings; $n$ is the total number of samples; $\sigma^{2}$ is the discrete variance of the study sample; $L$ is the number of samples in the secondary region; and $n_{i}$ and $\sigma_{i}{ }^{2}$ are the number of samples and discrete variance of region $i$, respectively.

GeoDetector requires variables to be hierarchical and discrete, and researchers discretize continuous data based on experience that is subjective and random [47]. To overcome this shortcoming, the natural breaks method is used to discretize continuous variables. The natural breaks method is the best break method under a given number of classifications, which minimize differences within intervals or maximize differences between intervals.

\subsubsection{Geospatial Analysis Software}

ArcGIS is a GIS spatial analysis tool developed by the Environmental Systems Research Institute (ESRI) in the United States. ArcGIS is a comprehensive system that collects, organizes, manages, analyzes, communicates, and classifies geographic information, and is a basic tool for making maps. It also has powerful spatial processing functions and can help users complete higher-level spatial analysis. There are eight main geoprocessing functions, including analysis tools, data management, conversion tools, spatial analyst tools, 3D analyst tools, geocoding tools, linear referencing, and coverage tools. This paper uses spatial analysis tools such as center of gravity and standard deviation ellipse to analyze the spatial distribution characteristics of green buildings in China. And through the spatial analysis of different time sections, it can dynamically reflect the time evolution law of green building development.

Stata is a statistical software that provides data analysis, data management, and professional charting. Its statistical analysis functions include parameter estimation, multivariate linear correlation analysis, curve fitting, residual analysis, diagnostic test evaluation, kappa, etc. This paper uses the 
Stata software to analyze the spatial correlation of green building development in China, including global correlation and local correlation, and draw Moran scatter plots.

\section{Spatial-Temporal Pattern Evolution of Green Buildings}

\subsection{Spatial Equilibrium of Green Building Development}

\subsubsection{Overall Spatial Equilibrium}

By observing the variation trends of coefficient of variation $(\mathrm{CV})$, development concentration $\left(C R_{n}\right)$, and spatial Gini coefficient $(G)$ in Table 2 over the past 11 years, it can be found that: (1) The variation coefficient $(\mathrm{CV})$ of China's green building development generally shows a downward trend in fluctuation. From 2008 to 2012, it decreased from 2.28 to 1.13, with a rapid decline; from 2013 to 2018, the decline was slow, and it increased slightly in 2015 and 2018, but the overall trend was downward. (2) The concentration of green building development in China is high, but the decline is obvious. From 2008 to $2018, C R_{4}$ decreased from $83.83 \%$ to $33.74 \%$, and $C R_{8}$ decreased from $100 \%$ to $69.28 \%$. (3) The space Gini coefficient $(G)$ was greater than 0.08 in 2008-2018, indicating that China's green building development was highly concentrated. But it dropped from 0.35 to 0.16 from 2008 to 2018, showing a downward trend in fluctuation. This is because with the improvement of China's concept of green sustainable development, more and more provinces encouraged green buildings through formulating regulations, policies, and incentives, and the green building development gap gradually narrowed. As Ei-Sharif et al. [48] have verified, government control measures can positively promote green building promotion.

It can be seen that the spatial imbalance of green buildings in China is relatively high and the clustering is obvious, but there is a large diffusion effect, and the spatial imbalance is gradually decreasing. On the whole, China's green buildings are spreading while they are in an aggregated state.

Table 2. Overall spatial equilibrium indicators of green building development in China (2008-2018).

\begin{tabular}{ccccc}
\hline Years & $\begin{array}{c}\text { CV } \\
\text { (Coefficient of } \\
\text { Variation) }\end{array}$ & $\begin{array}{c}\mathbf{C R}_{\mathbf{4}} \\
\text { (Concentration } \\
\text { Ratio of Top 4) }\end{array}$ & $\begin{array}{c}\mathbf{C R}_{\mathbf{8}} \\
\text { (Concentration } \\
\text { Ratio of Top 8) }\end{array}$ & $\begin{array}{c}\text { G } \\
\text { (Spatial Gini } \\
\text { Coefficient) }\end{array}$ \\
\hline 2008 & 2.280213 & 0.838284 & 1.000000 & 0.350510 \\
2009 & 2.573852 & 0.860018 & 0.997210 & 0.398468 \\
2010 & 1.679797 & 0.583869 & 0.807012 & 0.304874 \\
2011 & 1.324509 & 0.512246 & 0.692776 & 0.244545 \\
2012 & 1.132941 & 0.442163 & 0.673106 & 0.199705 \\
2013 & 0.865042 & 0.365547 & 0.564079 & 0.175363 \\
2014 & 0.820792 & 0.354632 & 0.551861 & 0.122449 \\
2015 & 0.959384 & 0.426735 & 0.591439 & 0.144222 \\
2016 & 0.808787 & 0.318777 & 0.544913 & 0.171737 \\
2017 & 0.723756 & 0.292637 & 0.521377 & 0.158440 \\
2018 & 0.777502 & 0.337425 & 0.542185 & 0.158314 \\
\hline
\end{tabular}

\subsubsection{Local Spatial Equilibrium}

By calculating the location entropy $(Q)$ of green building development in each province from 2008 to 2018, the local spatial equilibrium of green buildings in China was analyzed. The larger the $Q$ is, the higher the concentration of green building in the region. The study found that the regional entropy varies greatly among provinces. There are nine provinces with an average entropy greater than 1 (that is, above average), including Shanghai, Tianjin, Jiangsu, Beijing, Guangdong, Jiangxi, Shaanxi, Hubei, and Zhejiang (Figure 1). Among them, Shanghai (4.51), Tianjin (2.65), Jiangsu (2.49), and Beijing (2.25) are greater than 2, which means that their green building development level is much higher than other provinces. However, from the perspective of temporal evolution in 2008-2018 (Figure 2), the difference among provinces decreased significantly, that is, the spatial equilibrium of green building 
development is gradually increasing. The spatial agglomeration of green buildings also occurs in other countries and regions. For example, Cidell [20] counted the geographic distribution of 941 LEED certification projects in the United States, and found that green buildings are concentrated in the Pacific Northwest, the Rocky Mountains, the Upper Midwest, and the East Coast, while areas with relatively few green buildings include Southern California, the Great Plains, the Ohio River Valley, and the South. Kahn et al. [22] analyzed the geospatial distribution of green buildings in California, and found that the addresses of green building owners are concentrated, and they are all concentrated in the urban areas or coastal areas of California.

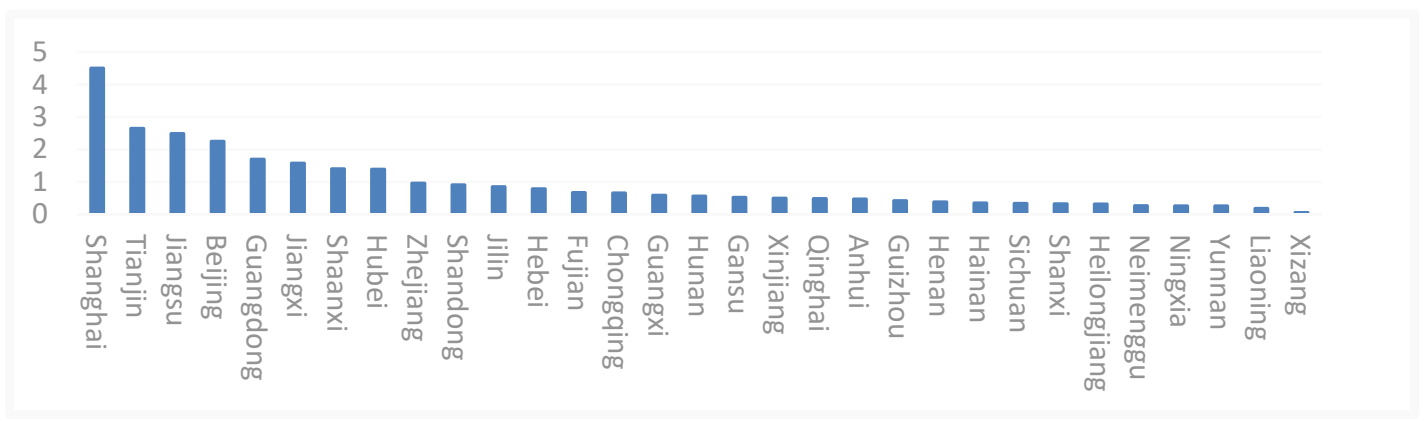

Figure 1. Average location entropy of green buildings in China between 2008 and 2018.

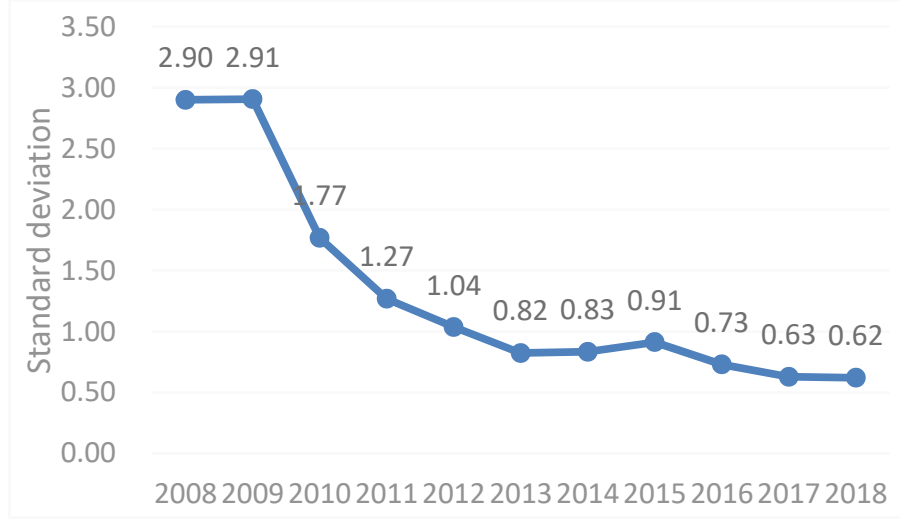

Figure 2. Standard deviation of location entropy of green buildings in China (2008-2018).

In order to improve the spatial equilibrium of the development of green buildings in China, the exchanges of green building policies, technology, and culture among regions should be strengthened. A green building cluster has formed in the central and eastern part of China, and it should play the role of a green building leader, actively innovate green building technology, and explore green building development models. These regions should help promote green building development in other regions and reduce imbalances. The development of green buildings in the western and northeastern regions of China is relatively backward, and they should actively learn from other regions about green building innovative technologies and management models. These areas should improve the green building regulation system and evaluation standards, adopt financial subsidies, tax reductions, and other incentives for developers and consumers, and increase public acceptance of green buildings through publicity and other methods.

\subsection{Spatial-Temporal Distribution Characteristics of Green Buildings}

The green building development level is measured by the ratio of green building label projects area to new construction area in each province, and the green building distribution map is shown in Figure 3. With the help of ArcGIS software, this paper used the standard deviation ellipse method to analyze the spatial-temporal pattern evolution of China's green buildings. The center of gravity and standard 
deviation ellipse of green buildings in 2011-2018 are shown in Figure 4, and the parameters data are shown in Table 3. During 2008-2010, most provinces had low levels of green building development, and the data are poorly analyzable, so data from 2008 to 2010 are excluded.
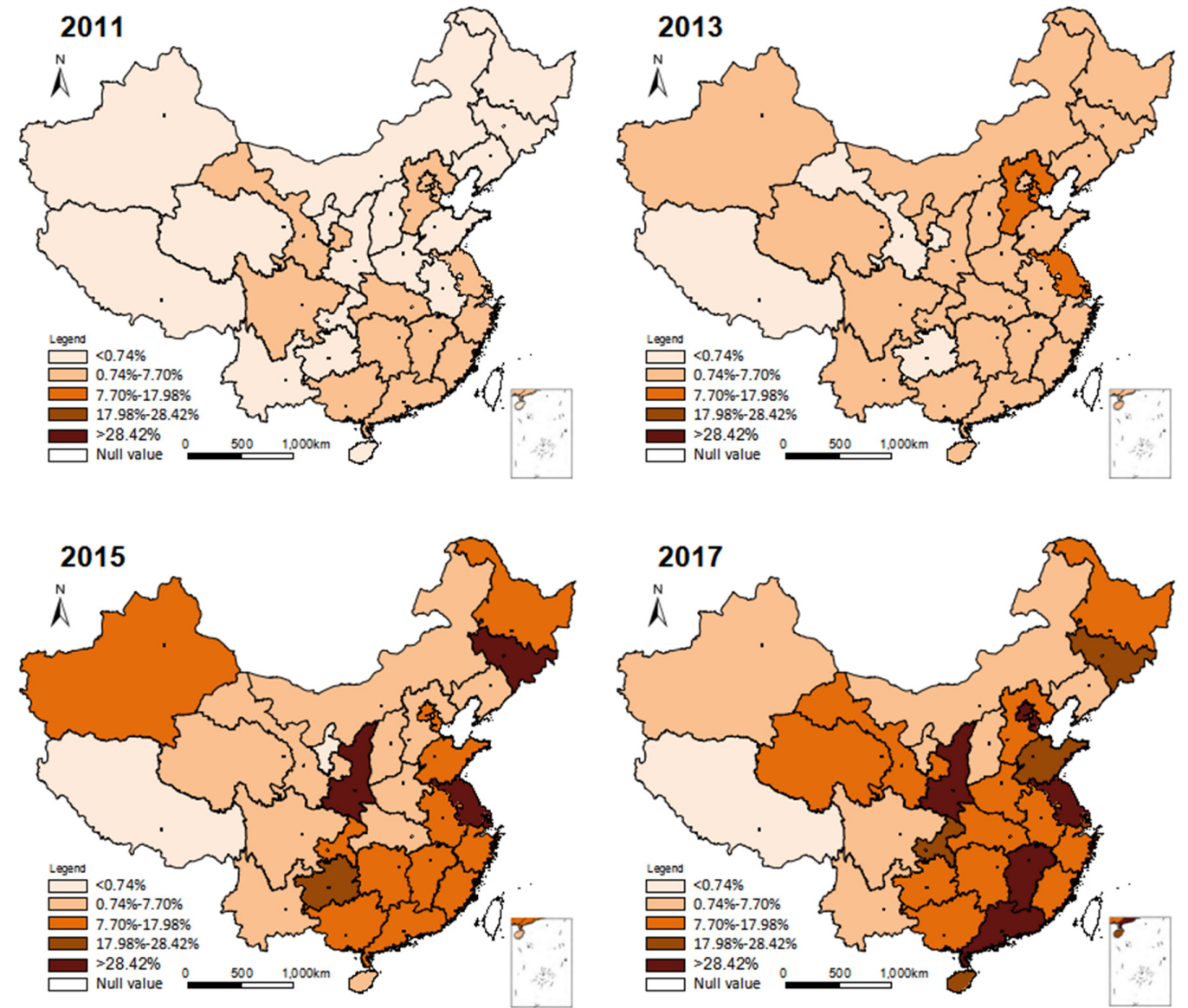

Figure 3. Distribution of green buildings in China in 2011, 2013, 2015, and 2017.

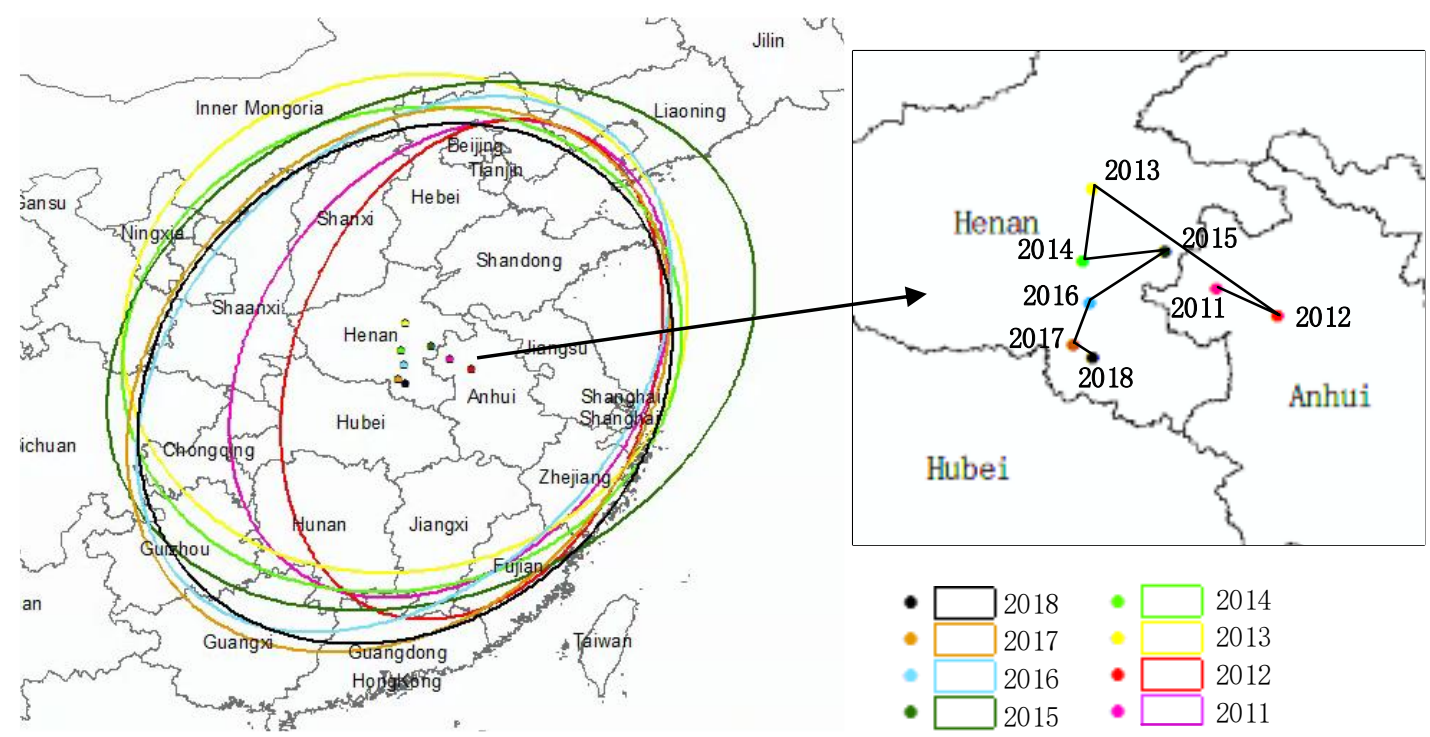

Figure 4. Centers of gravity and standard deviation ellipses of green buildings in China (2011-2018). 
Table 3. Parameters data of standard deviation ellipses from 2011 to 2018.

\begin{tabular}{|c|c|c|c|c|c|}
\hline Year & $\begin{array}{c}\text { Ellipse } \\
\text { Area/10,000 km² }\end{array}$ & $\begin{array}{c}\text { Center of } \\
\text { Gravity } \\
\text { Coordinates }\end{array}$ & $\begin{array}{c}\text { Major Axes } \\
\text { Standard } \\
\text { Deviation/km }\end{array}$ & $\begin{array}{c}\text { Minor Axes } \\
\text { Standard } \\
\text { Deviation/km }\end{array}$ & $\begin{array}{c}\text { Rotation } \\
\text { Angles }\end{array}$ \\
\hline 2011 & 174.1071 & $\begin{array}{l}33.1049^{\circ} \mathrm{N}, \\
115.7712^{\circ} \mathrm{E}\end{array}$ & 1472.8020 & 579.1046 & $37.0358^{\circ}$ \\
\hline 2012 & 159.7028 & $\begin{array}{l}32.7666^{\circ} \mathrm{N}, \\
116.5019^{\circ} \mathrm{E}\end{array}$ & 639.7082 & 866.3833 & $20.9925^{\circ}$ \\
\hline 2013 & 242.3666 & $\begin{array}{l}34.2856^{\circ} \mathrm{N} \\
114.2957^{\circ} \mathrm{E}\end{array}$ & 592.1388 & 858.5509 & $75.5887^{\circ}$ \\
\hline 2014 & 233.3927 & $\begin{array}{l}33.4132^{\circ} \mathrm{N} \\
114.1887^{\circ} \mathrm{E}\end{array}$ & 942.8528 & 818.2798 & $74.8857^{\circ}$ \\
\hline 2015 & 287.9023 & $\begin{array}{l}33.5296^{\circ} \mathrm{N}, \\
115.1566^{\circ} \mathrm{E}\end{array}$ & 936.7298 & 793.1339 & $66.4003^{\circ}$ \\
\hline 2016 & 231.9770 & $\begin{array}{l}32.9269^{\circ} \mathrm{N} \\
114.2625^{\circ} \mathrm{E}\end{array}$ & 1115.3453 & 821.6950 & $44.7617^{\circ}$ \\
\hline 2017 & 246.6239 & $\begin{array}{l}32.4236^{\circ} \mathrm{N} \\
114.0733^{\circ} \mathrm{E}\end{array}$ & 718.4983 & 1027.7707 & $44.5859^{\circ}$ \\
\hline 2018 & 235.3773 & $\begin{array}{l}32.2838^{\circ} \mathrm{N} \\
114.2981^{\circ} \mathrm{E}\end{array}$ & 777.2204 & 1010.1036 & $48.9784^{\circ}$ \\
\hline
\end{tabular}

\subsubsection{Center of Gravity of Green Buildings}

The centers of gravity of ellipses are distributed on the border between Henan and Anhui provinces. The center of gravity was in Anhui province before 2013, and in Henan province in 2013 and after. In terms of the trajectory of the center of gravity, there is a law of moving northwest and then south in the whole.

From 2011 to 2013, the center of gravity first moved southeast and then northwest, with a displacement of $189.377 \mathrm{~km}$. It is possible to compare the distribution of green buildings in Figure 3 . It can be found that in 2011, China's green building was in the primary stage, and most provinces had a poor green building development, with Tianjin, Shanghai, and Jiangsu taking the lead. In 2012, with the development of green buildings in the southeast coastal provinces, the center of gravity moved to the southeast. In 2013, there was a significant development in green building in northern provinces (including Hebei, Beijing, Heilongjiang, Neimenggu, etc.) and Midwestern provinces (including Qinghai, Shanxi, Shanxi, Shaanxi, Henan, etc.), shifting the center of gravity to the northwest.

From 2013 to 2018, the center of gravity moved gradually from north to south, with a displacement of $222.579 \mathrm{~km}$. It is possible to compare the distribution of green buildings in Figure 3. It can be found that in 2013-2018, the development speed of green buildings in the southern provinces was faster than that in the north, and the overall level was higher than in the north, which made the center of green buildings move southward year by year. Among them, there was a trend of eastward movement in 2014-2015, which was due to the obvious development of green buildings in the eastern coastal areas in 2015.

\subsubsection{Distribution Range of Green Buildings}

The area of the standard deviation ellipse showed a volatile growth trend, which increased from 17.411 million $\mathrm{km}^{2}$ in 2011 to 23.538 million $\mathrm{km}^{2}$ in 2018. The trend of spatial expansion is obvious. Among them, 2013 and 2015 had the largest increases, of 826,600 $\mathrm{km}^{2}$ and 545,100 km², respectively. However, there were slight downward trends in 2014, 2016, and 2018, indicating that the range of green buildings was unstable and fluctuating.

The ellipse covers the eastern coastal areas of the Yangtze River Delta, Beijing-Tianjin-Hebei, Shandong, Fujian, and central regions such as Hubei, Hunan, Anhui, Jiangxi, and Henan. These provinces dominate the development of green buildings in China. From 2011 to 2012, the coverage of the ellipse was mainly in the eastern provinces. In 2013, it moved significantly to the west, covering the 
central and western regions of Shaanxi, Sichuan, Guizhou, and Ningxia. This is due to the vigorous development of green buildings in central and northern provinces of China in 2013. From 2013 to 2018, the coverage range of ellipse changed little and rose in a fluctuating manner.

\subsubsection{Distribution Direction of Green Buildings}

This paper studied the distribution direction of green buildings based on the rotation angle of the standard deviation ellipse. From 2011 to 2018, the ellipse showed a spatial pattern of a northeast-southwest direction, and the rotation angle first increased and then decreased.

In 2011-2013, the rotation angle changed greatly. From 2011 to 2012, it decreased from $37.04^{\circ}$ to $20.99^{\circ}$. This is mainly due to the development of green buildings in Beijing-Tianjin-Hebei and the Pearl River Delta in 2012, which caused the ellipse to rotate counterclockwise. From 2012 to 2013, the rotation angle increased from $20.99^{\circ}$ to $75.59^{\circ}$. This is due to the development of green buildings in the central and western regions of China in 2013. The ellipse expanded in the east-west direction, and the directionality of the ellipse was not obvious.

In 2013-2018, the rotation angle decreased from $75.59^{\circ}$ to $48.98^{\circ}$. In recent years, the corner has stabilized, and the spatial pattern of northeast-southwest has been strengthened. China has formed a green building cluster in northeast-southwest direction, with Beijing-Tianjin-Hebei, the Yangtze River Delta and the Pearl River Delta regions as the core.

\subsubsection{Distribution Shape of Green Buildings}

By observing the changes of major and minor axes standard deviation from 2011 to 2018 in Table 3, we analyzed the distribution shape of green buildings in China. The minor axes standard deviation increased from $639.71 \mathrm{~km}$ in 2010 to $954.29 \mathrm{~km}$ in 2018, indicating that the east-west direction of the ellipse is expanding. Among them, the minor axes standard deviation increased by $475.64 \mathrm{~km}$ in 2011-2015, decreased by $396.85 \mathrm{~km}$ in 2015-2016, and increased by $235.80 \mathrm{~km}$ in 2016-2018. The major axes standard deviation decreased from $866.38 \mathrm{~km}$ in 2011 to $785.16 \mathrm{~km}$ in 2018, indicating that the ellipse contracted in the north-south direction, but the change trend was not obvious. Among them, the major axes' standard deviation was reduced by $73.25 \mathrm{~km}$ from 2011-2014, increased by $234.64 \mathrm{~km}$ from 2014-2016, and decreased by $242.62 \mathrm{~km}$ from 2016-2018.

Generally speaking, the ellipse of green buildings has shortened the long axis and increased the short axis from 2011 to 2018. It shows that the distribution of green buildings in China has an expansion trend in the east-west direction and a contraction trend in the north-south direction. However, the east-west expansion trend is obvious, the north-south contraction trend is small, and the ellipse tends to be round. It can be seen that the directionality of the distribution of green buildings in China has weakened, and the distribution range has gradually increased.

\subsection{Spatial Correlation of Green Buildings}

In order to explore the spatial correlation of green buildings in China, this paper uses an adjacent matrix and an economic distance matrix to calculate the global Moran's indexes of green buildings from 2008 to 2018, and draws local Moran scatter plots. The results are shown in Table 4 and Figure 5, and it can be concluded that:

(1) The global Moran's indexes calculated using adjacent weights and economic distance weights are all greater than 0 , indicating that the development of green buildings in China has a positive space spillover effect. From the perspective of adjacent weights, neighboring provinces learn from each other's green building knowledge and technology, policies and regulations, and economic incentives, and disseminate the concept of green consumption among residents, which makes green buildings have spatial agglomeration characteristics and space spillover effects on neighboring relationships. Based on the calculation results of economic distance weights, provinces with similar economic levels have formed close relations in terms of green building technology sharing, policy standards penetration, and construction production factors flow, so that the development of green buildings has spillover 
effects through economic ties. According to the local Moran scatter plots, it can be found that most provinces are in the third quadrant (low-low clusters), and in the first quadrant (high-high clusters) are the Beijing-Tianjin-Hebei region and the Yangtze River Delta region. It can be seen that in the early stages of green building development, the two economic circles formed good spatial agglomeration effects, and were the leading forces in the development of green buildings in China.

(2) The Moran's indexes calculated using the economic matrix are generally higher than the adjacency matrix, indicating that green buildings development in provinces with similar economic levels in our country has a stronger spatial correlation than geographically adjacent provinces, and the spillover effect of green buildings through economic ties is higher than that through geographical adjacency. Regions with similar economic levels can better learn green building knowledge and technology, policies and regulations, and incentive measures from each other, and can better spread green building consumption concepts.

(3) From the perspective of evolution, the Moran indexes calculated with two spatial weights both show a trend of reducing fluctuations, and the spatial positive correlation changed from significant to insignificant. These results can be discussed in three stages: (1) from 2008 to 2009, China's green buildings were in their infancy, and only a few provinces had green building label projects. There was no obvious spatial clustering pattern, and the spatial correlation was small and insignificant; (2) from 2010 to 2014, the Moran's indexes with two weights both first increased and then decreased and met the significance of $1 \%$. The Moran's index with adjacency weight increased from 0.268 in 2010 to 0.322 in 2012 and then decreased to 0.259 in 2014. The Moran's index with economic distance weight increased from 0.448 in 2010 to 0.630 in 2011 and then decreased to 0.346 in 2014. This shows that there is an obvious positive spatial correlation in the early stage of green building development in China, and this correlation is the most obvious in 2011-2012. By observing the local Moran scatter plots shown in Figure 5, it can be found that most provinces are in the third quadrant, that is, in a low-low aggregation spatial pattern. The Beijing-Tianjin-Hebei region and the Yangtze River Delta region have formed high-high cluster patterns, and are the leading regions for the development of green buildings in China; 3) from 2015 to 2018, the Moran's indexes with two weights were both less than 0.2 and not significant. Green building had weak autocorrelation, and its spatial clustering characteristics were not obvious. As provinces attach more and more importance to green sustainable development, a large number of green building policies and regulations, evaluation standards, and incentives (including tax benefits, plot ratio rewards, financial subsidies, etc.) were introduced in 2014-2015, which led to the development of green buildings in most provinces. This broke the spatial pattern of low-low aggregation, causing the Moran's index to decrease significantly and lose significance.

Table 4. Global Moran's index of green building development in China (2008-2018)

\begin{tabular}{|c|c|c|c|c|c|c|c|}
\hline \multirow{2}{*}{ Year } & \multicolumn{3}{|c|}{ Adjacency Matrix } & \multirow{2}{*}{ Year } & \multicolumn{3}{|c|}{ Economic Distance Matrix } \\
\hline & Moran's I & $\mathrm{Z}$ & P-Value & & Moran's I & $\mathrm{Z}$ & P-Value \\
\hline 2008 & 0.079 & 1.023 & 0.153 & 2008 & 0.057 & 0.838 & 0.201 \\
\hline 2009 & 0.056 & 0.962 & 0.168 & 2009 & 0.550 & 6.417 & 0.000 \\
\hline 2010 & 0.268 & 3.104 & 0.001 & 2010 & 0.448 & 5.008 & 0.000 \\
\hline 2011 & 0.272 & 2.859 & 0.002 & 2011 & 0.630 & 6.381 & 0.000 \\
\hline 2012 & 0.322 & 3.084 & 0.001 & 2012 & 0.405 & 3.908 & 0.000 \\
\hline 2013 & 0.278 & 2.777 & 0.003 & 2013 & 0.291 & 2.966 & 0.002 \\
\hline 2014 & 0.259 & 2.590 & 0.005 & 2014 & 0.346 & 3.451 & 0.000 \\
\hline 2015 & 0.123 & 1.372 & 0.085 & 2015 & 0.058 & 0.820 & 0.206 \\
\hline 2016 & 0.013 & 0.020 & 0.492 & 2016 & 0.077 & 0.952 & 0.171 \\
\hline 2017 & 0.165 & 1.655 & 0.049 & 2017 & 0.052 & 0.731 & 0.232 \\
\hline 2018 & 0.080 & 0.973 & 0.165 & 2018 & 0.035 & 0.600 & 0.274 \\
\hline
\end{tabular}




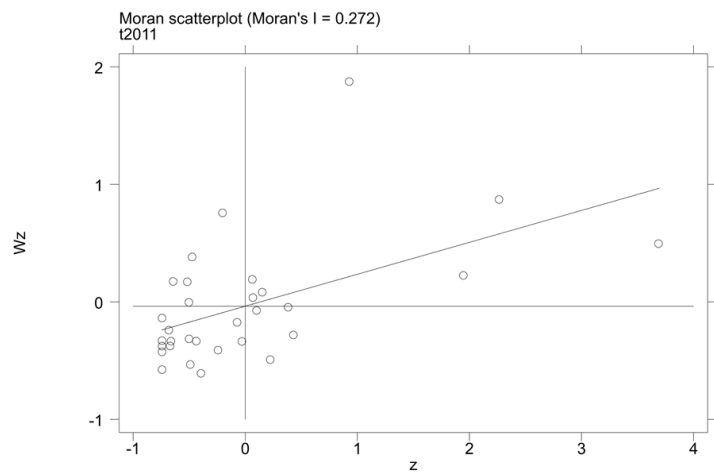

(a)

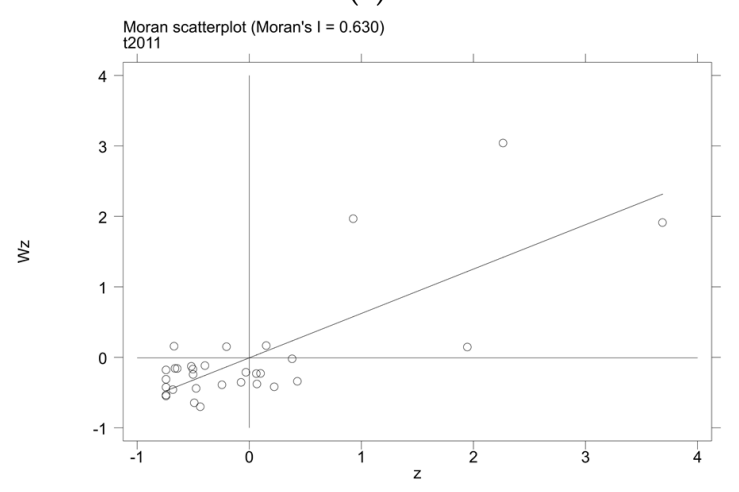

(c)

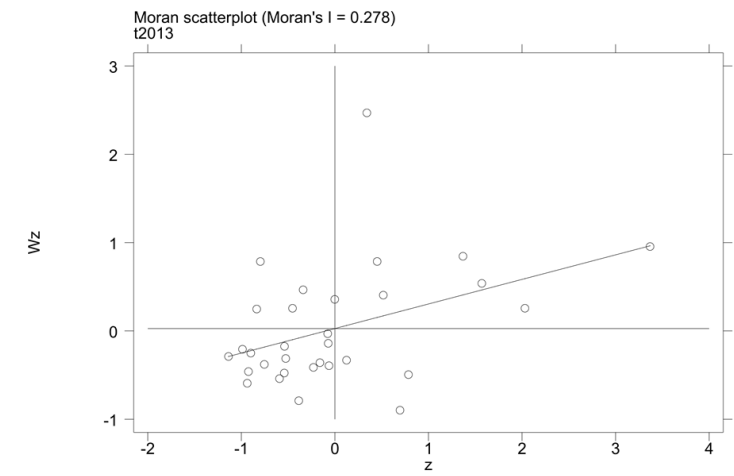

(b)

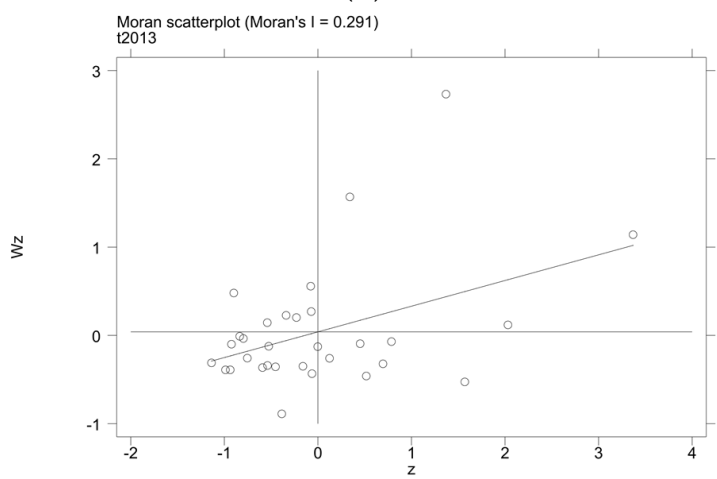

(d)

Figure 5. Local Moran scatter plots of green buildings development in China based on two spatial weight matrices in 2011 and 2013: (a,b) adjacency matrix; (c,d) economic distance matrix.

\section{Driving Factors of Green Building Development}

This paper used the natural breaks method to classify continuous detection factors into five categories. It then used factor detectors to calculate the explanatory power $(q)$ of factors for the development of green buildings, and use interactive detectors to measure the interaction between factors in 2012, 2014, 2016, and 2018. In order to study the factors' effects on areas with different levels of green building development, this paper divided China's 31 provinces into three stages: green building high-level, mid-level, and low-level areas, which was based on the green building data in 2018, and used the natural breaks method. The detection results are shown in Table 5: 
Table 5. Detection results of driving factors for green building development in China.

\begin{tabular}{|c|c|c|c|c|c|c|c|c|}
\hline \multicolumn{2}{|c|}{ Detection Factors } & \multirow{2}{*}{$\begin{array}{l}2012 \\
0.25\end{array}$} & \multirow{2}{*}{$\begin{array}{c}2014 \\
0.28\end{array}$} & \multirow{2}{*}{$\begin{array}{c}2016 \\
0.16\end{array}$} & \multirow{2}{*}{$\begin{array}{l}2018 \\
0.21\end{array}$} & \multirow{2}{*}{$\begin{array}{c}\begin{array}{c}\text { High-Level } \\
\text { Area }\end{array} \\
0.19\end{array}$} & \multirow{2}{*}{$\begin{array}{c}\begin{array}{c}\text { Mid-Level } \\
\text { Area }\end{array} \\
0.37\end{array}$} & \multirow{2}{*}{$\begin{array}{c}\begin{array}{c}\text { Low-Level } \\
\text { Area }\end{array} \\
0.19\end{array}$} \\
\hline Government Regulation & Regulations (RE) & & & & & & & \\
\hline Measures & Incentives (INC) & 0.04 & 0.09 & 0.14 & 0.17 & 0.36 & 0.19 & 0.06 \\
\hline & Baidu Index (BD) & 0.24 & 0.23 & 0.25 & 0.26 & 0.30 & 0.38 & 0.61 \\
\hline Public Purchasing Attitude & Education Level (EDU) & 0.34 & 0.51 & 0.24 & 0.18 & 0.61 & 0.25 & 0.27 \\
\hline Economic and Technological & Technical Level (TEC) & 0.32 & 0.26 & 0.22 & 0.24 & 0.35 & 0.51 & 0.07 \\
\hline Environment & Economic Level (GDP) & 0.59 & 0.56 & 0.34 & 0.34 & 0.18 & 0.44 & 0.09 \\
\hline Dominant Interaction Factor & & $\begin{array}{c}\mathrm{RE} \cap \mathrm{GDP} \\
0.83\end{array}$ & $\begin{array}{c}\text { RE } \cap \text { TEC } \\
0.89\end{array}$ & $\begin{array}{c}\text { RE } \cap \text { EDU } \\
0.76\end{array}$ & $\begin{array}{c}\text { RE } \cap \text { EDU } \\
0.77\end{array}$ & $\begin{array}{c}\text { EDU } \cap \text { TEC } \\
0.87\end{array}$ & $\begin{array}{c}\mathrm{RE} \cap \mathrm{BD} \\
0.85\end{array}$ & $\begin{array}{c}\text { RE } \cap \text { EDU } \\
0.93\end{array}$ \\
\hline
\end{tabular}


(1) Observe the q-value of each detection factor in 2012, 2014, 2016, and 2018. From the perspective of the main influencing factors, economic level (GDP), technical level (TEC), and education level (EDU) have a high explanatory power for the development level of green buildings. In addition, the influence of the economic and technological environment and public purchasing attitude on the development of green buildings is higher than the government regulation measures. It can be seen that the government's regulatory role in green buildings is limited, and the development of green buildings mainly depends on the local economic and technological environment and the public quality level. Kats et al. [10] pointed out that buildings that achieve LEED certification cost $1.84 \%$ more than conventional buildings on average, and the additional cost of achieving LEED gold certification is about $2-5 \%$. The development of the economy and technology can reduce the development cost of green buildings and increase the enthusiasm of real estate developers.

This conclusion is also applicable in other countries and regions. Al-Thani et al. [49] thought that the development of smart technology can contribute significantly to a neighborhood's sustainability and livability. Tokbolat et al. [50] suggested paying attention to introducing and improving the green building certification and technical support level. In terms of specific technology applications, Liu et al. [51] explored how to fully integrate BIM (Building Information Modeling) technology with Singapore's Green Mark standard evaluation. Fuerst et al. [21] believed that there is a positive correlation between the number of green building projects and the level of urban economic development.

From the perspective of evolution, the explanatory power of regulations (RE), education level (EDU), and economic level (GDP) has declined, while the explanatory power of incentives (INC) has significantly improved. It shows that with the development of green buildings and the strengthening of government regulation, the dependence of green buildings on the level of economy and public education has decreased, and the role of government regulation, especially incentives, has gradually increased. In studies in other countries, government regulation was also an important driving factor for green buildings. Amstalden et al. [29] researched the Swiss green building market and found that the government's incentives can positively promote the number of green building investments and transactions. Dongping et al. [52] studied the policy system of green buildings in the United States, and believed that the successful promotion of green buildings in the United States depended on feasible regulations and policies and the support of incentive measures.

(2) Zuo et al. [53] confirmed that the critical success factors to achieve green building are usually interactive; therefore a comprehensive consideration of them is required. In the results of the interaction of the factors in this study, there are mutually reinforcing interactions among factors, indicating that each driving factor does not play a separate role in the development of green buildings, but interacts with other factors. Among them, the explanatory power of regulations (RE), education level (EDU), and technology level (TEC) interacting with other factors are mostly stronger than the sum of single factor q-values, that is, showing nonlinear enhancement. In particular, although regulations (RE) are inferior to the public purchasing attitude and economic and technological environment in terms of single-factor influence, they have become the dominant interaction factor when combined with other factors. That is, the government's green building regulations and policies need to coordinate with the economy, technology, and resident quality to promote the development of green buildings. In a similar study, Monfared et al. [54] studied the interactions between factors from the perspective of the occupants. They believed that there are interactive relationships between occupants' attitudes towards green buildings, building performance, and occupants' satisfaction with buildings.

(3) From a market perspective, Kahn et al. [22] revealed that consumers' acceptance of green buildings is different in different geographical locations, hence it is necessary to explore the driving factors of green buildings by region. Observe the q-value of detection factors in the green building high-level, mid-level, and low-level area. We found that low-level and high-level areas are mainly affected by public purchasing attitudes, while in the mid-level area the economic and technological environment has a greater influence. In a similar study, Ming et al. [55] divided green buildings into three stages: an initial stage, a development stage, and a mature stage. They believed that in the initial 
stage, green building development costs are high, and consumers are concerned about the house price; in the development stage, development costs are reduced, and consumers are concerned about product quality; and in the mature stage, green buildings replace traditional buildings and the market can effectively allocate resources.

The influencing factors have different effects on regions with different levels of green building development. Therefore, specific suggestions are proposed for different levels of regions. In the green building low-level area, local governments should actively develop and introduce green building innovative technologies, improve the green building regulations system and evaluation standards, adopt financial subsidies, tax reductions, and other incentives for developers and consumers, and adjust the failure of the green building market. In the green building mid-level area, local governments should further improve government regulation measures and vigorously promote green building technologies to provide policy support and a technical foundation for green building development. In the green building high-level area, local governments should increase public awareness and acceptance of green buildings through propaganda and policy subsidy support, reduce the government's control over the market, establish an effective green building supervision system, and gradually bring the market into play.

\section{Conclusions}

In the 21st century, when resources are excessively consumed and environmental pollution is severe, sustainable development is the goal pursued by all mankind. Green buildings use the principles of efficient resource utilization, ecological harmonious development, and health and comfort throughout the life cycle of the building. It is the embodiment of sustainable development in the construction field, and is the focus of global development today.

This paper collected the spatial panel data of China's green building label projects from 2008 to 2018 to study the spatial pattern and evolution of green buildings in China. By using regional difference indexes, the standard deviation ellipse method, and the spatial autocorrelation method, the spatial equilibrium, spatial distribution, and spatial correlation of green buildings in China were studied, respectively. Further, we established a driving factors system of green building, and used the GeoDetector to measure and analyze the explanatory power and interaction of factors.

The mastery and research on the spatiotemporal evolution characteristics and driving factors of green building development is an important basis for guiding the innovative practice of green building development and the formulation of planning policies. Globally, some scholars have done research in this area; Kaza [19], Cidell [20], Fuerst [21], and Kahn [22] studied the spatial distribution characteristics of green buildings in the United States. Most of these studies have found that the geographical distribution of green buildings presents certain differences and clustering characteristics. However, there are few studies on the spatial-temporal evolution of green buildings in China. In the early days, scholars such as Zuda [40] and Baoxing [23] did some research. But their researches collected little data, and the results have limited reference value for current research on green buildings. This paper enriches the research on the distribution of green buildings and its driving factors in China, and can provide a basis and reference for other related research.

The use and promotion of green buildings is the fundamental way to improve the human living environment, reduce building energy consumption, and solve energy problems. Provinces should formulate targeted and adaptive measures to promote the development of green buildings according to their own conditions (such as green building development status, economic level, population size, residents' quality, and technical level), and adjust the failure of the green building market through government intervention. Meanwhile, the government should vigorously promote green building technology and provide technical support for green buildings. Additionally, through the publicity of green buildings, policy subsidies and other methods should be implemented to improve public awareness and acceptance of green buildings. 
There are still many limits to this research, which are also the directions for further study. Limited by the availability of data, it may not be accurate enough to select only the green building label projects to measure the development status of green buildings in China. In addition, in theory, the development of green buildings should be affected by more factors, and the indicator system of driving factors established in this study based on available data and existing research results may be incomplete. It is recommended that subsequent studies be analyzed with more complete variable data. The large-scale development of green buildings will inevitably lead to the industrialization of green buildings. Future research can take the green building industry as a research object, explore its development process and agglomeration phenomena, and analyze its development bottlenecks and obstacles.

Author Contributions: Conceptualization, Y.G., G.Y., and Q.X.; data curation, Y.G. and Q.X.; formal analysis, Y.G., G.Y., and Q.X.; writing—original draft, Y.G.; writing—review and editing, Y.G., G.Y., and Q.X. All authors have read and agreed to the published version of the manuscript.

Funding: This research was funded by the Fundamental Research Funds for the Central Universities (Project No. B200203028) and the National Natural Science Foundation of China (Project No. 71402045).

Conflicts of Interest: The authors declare no conflicts of interest.

\section{References}

1. IPCC. Climate Change 2007, the Fourth Assessment Report (AR4) of the United Nations Intergovernmental Panelon Climate Change; TERI: Geneva, Switzerland, 2008.

2. No, S.; Won, C. Comparative Analysis of Energy Consumption between Green Building Certified and Non-Certified Buildings in Korea. Energies 2020, 13, 1049. [CrossRef]

3. Technology and Industrialization Development Center of the Ministry of Housing and Urban-Rural Development. World Green Building Policy Law and Evaluation System; China Architecture \& Building Press: Beijing, China, 2014; pp. 78-80.

4. Qiu, Y.; Tiwari, A.; Wang, Y.D. The diffusion of voluntary green building certification: A spatial approach. Energy Effic. 2015, 8, 449-471. [CrossRef]

5. Zhang, Y.; Wang, J.; Hu, F.; Wang, Y. Comparison of evaluation standards for green building in China, Britain, United States. Renew. Sustain. Energy Rev. 2017, 68 Pt 1, 262-271. [CrossRef]

6. Darko, A.; Chan, A.P.C. Strategies to promote green building technologies adoption in developing countries: The case of Ghana. Build. Environ. 2018, 130, 74-84. [CrossRef]

7. Olubunmi, O.A.; Xia, P.B.; Skitmore, M. Green building incentives: A review. Renew. Sustain. Energy Rev. 2016, 59, 1611-1621. [CrossRef]

8. Chan, A.P.C.; Darko, A.; Ameyaw, E.E. Strategies for Promoting Green Building Technologies Adoption in the Construction Industry-An International Study. Sustainability 2017, 9, 969. [CrossRef]

9. Hwang, B.-G.; Shan, M.; Phua, H.; Chi, S. An exploratory analysis of risks in green residential building construction projects: The case of Singapore. Sustainability 2017, 9, 1116. [CrossRef]

10. Kats, G.; Alevantis, L.; Berman, A.; Mills, E.; Perlman, J. The Costs and Financial Benefeits of Green Buildings. In A Report to California's Sustainable Building Task Force; California Department of Resources Recycling and Recovery: Sacramento, CA, USA, 2003; p. 134. Available online: http://www3.cec.org/islandora-gb/en/ islandora/object/islandora\%3A941 (accessed on 1 October 2003).

11. Kaplan, S.; Matthiessen, L.; Morris, P.; Unger, R.; Sparko, A. Cost of Green in NYC; USGBC; Urban Green Council: New York, NY, USA, 2009; p. 10.

12. Tollin, H.M. Green Building Risks: It's not easy being green. Environ. Claims J. 2011, 23, 199-213. [CrossRef]

13. Patrick, X.W.Z.; Couani, P. Managing risks in green building supply chain. Archit. Eng. Des. Manag. 2012, 8, 143-158.

14. Madew, R. Green buildings: The easy answer for sustainability. Aust. Plan. 2007, 44, 16-17. [CrossRef]

15. Švajlenka, J.; Kozlovská, M.; Pošiváková, T. Analysis of Selected Building Constructions Used in Industrial Construction in Terms of Sustainability Benefits. Sustainability 2018, 10, 4394. [CrossRef]

16. Švajlenka, J.; Kozlovská, M. Evaluation of the efficiency and sustainability of timber-based construction. J. Clean. Prod. 2020. [CrossRef] 
17. Cidell, J.; Beata, A. Spatial variation among green building certification categories: Does place matter? A rejoinder to Pushkar. Landsc. Urban Plan. 2009, 91, 142-151. [CrossRef]

18. Baoxing, Q. New Normal-New Green Building-The Current Situation and Development Prospect of Green Building in China. Constr. Sci. Technol. 2015, 12, 8-11.

19. Kaza, N.; Lester, T.W.; Rodriguez, D.A. The Spatiotemporal Clustering of Green Buildings in the United States. Urban Stud. 2013, 16, 3262-3282. [CrossRef]

20. Cidell, J. Building Green: The Emerging Geography of LEED Certified Buildings and Professionals. Prof. Geogr. 2009, 2, 200-215. [CrossRef]

21. Fuerst, F.; Kontokosta, C.; McAllister, P. Taking the LEED? Analyzing Spatial Variations in Market Penetration Rates of Eco-Labeled Properties. Real Estate Plan. Work. Pap. 2011, 41, 551-570.

22. Kahn, M.; Vaughn, R. Green Market Geography: The Spatial Clustering of Hybrid Vehicles and LEED Registeres Buildigs. BE J. Econ. Anal. Policy 2009, 9. [CrossRef]

23. Baoxing, Q.; Donghong, L.; Zhiqiang, W. Study on the Character of Chinese Green Building Spatial Evolution. Urban Dev. Stud. 2017, 24, 1-10.

24. Zou, Y.; Zhao, W.; Zhong, R. The spatial distribution of green buildings in China: Regional imbalance, economic fundamentals, and policy incentives. Appl. Geogr. 2017, 88, 38-47. [CrossRef]

25. Large, R.O.; Thomsen, C.G. Drivers of green supply management performance: Evidence from Germany. J. Purch. Supply Manag. 2011, 17, 176-184. [CrossRef]

26. Deng, Y.; Wu, J. Economic returns to residential green building investment: The developers' perspective. Reg. Sci. Urban Econ. 2014, 47, 35-44. [CrossRef]

27. Abidin, N.Z. Investigating the awareness and application of sustainable construction concept by Malaysian developers. Habitat. Int. 2010, 34, 421-426. [CrossRef]

28. Ruparathna, R.; Hewage, K. Sustainable procurement in the Canadian construction industry: Current practices, drivers and opportunities. J. Clean. Prod. 2015, 109, 305-314. [CrossRef]

29. Amstalden, R.W.; Kost, M.; Nathani, C.; Imboden, D.M. Economic potential energy-efficient retrofitting in the Swiss residential building sector: The effects of policy instruments and energy price expectations. Energy Policy 2007, 35, 19-29. [CrossRef]

30. Zhang, L.; Chen, L.; Wu, Z. Investigation young consumers' purchasing intention of green housing in China. Sustainability 2018, 10, 1044. [CrossRef]

31. Maichum, K.; Parichatnon, S.; Peng, K.-C. Application of the extended theory of planned behavior model to investigate purchase intention of green products among thai consumers. Sustainability 2016, 8, 1077. [CrossRef]

32. Yang, S.J.; Su, Y.K.; Wang, W. Research on developers' green procurement behavior based on the theory of planned behavior. Sustainability 2019, 11, 2949. [CrossRef]

33. Delmas, M.; Toffel, M.W. Stakeholders and environmental management practices: An institutional framework. Bus. Strategy Environ. 2004, 13, 209-222. [CrossRef]

34. Sarkis, J.; Gonzalez-Torre, P.; Adenso-Diaz, B. Stakeholder pressure and the adoption of environmental practices: The mediating effect of training. J. Oper. Manag. 2010, 28, 163-176. [CrossRef]

35. Henriques, I.; Sadorsky, P. The determinants of an environmentally responsive firm: An empirical approach. J. Environ. 1996, 30, 381-395. [CrossRef]

36. Ürge-Vorsatz, D.; Danny Harvey, L.D.; Mirasgedis, S.; Levine, M.D. Mitigating $\mathrm{CO}_{2}$ emissions from energy use in the world's buildings. Build. Res. Inf. 2007, 35, 392-393. [CrossRef]

37. Karkanias, C.; Boemi, S.N.; Papadopoulos, A.M.; Tsoutsos, T.D.; Karagiannidis, A. Energy efficiency in the Hellenic building sector: An assessment of the restrictions and perspectives of the market. Energy Policy 2010, 38, 2276-2784. [CrossRef]

38. Skea, J. Cold Comfort in a high Carbon Society. Build. Res. Inf. 2009, 1, 74-78. [CrossRef]

39. Wackernagel, M.; Onsite, L.; Bello, P. National natural capital accounting with the ecological footprint concept. Ecol. Econ. 1999, 29, 375-390. [CrossRef]

40. Zuda, Y. The Geography of Green Buildings in Chinese Cities. Mod. Urban Res. 2012, 27, 42-48.

41. Likun, Z.; Qibin, Z.; Junsen, T. Space-time Pattern Evolution and Spatial Correlation Analysis of Green Building in China-Based on Time Series Data from 2008-2015. Sci. Technol. Manag. Res. 2018, 3, 253-260.

42. Isa, M.; Rahman, M.M.G.M.A.; Sipan, I.; Hwa, T.K. Factors Affecting Green Office Building Investment in Malaysia. Procedia Soc. Behav. Sci. 2013, 105, 138-148. [CrossRef] 
43. Xinru, H. Research on Influencing Factors of Urban Green Building Development in the Context of Sustainable Development; Shenzhen University: Shenzhen, China, 2016.

44. Chan, E.H.W.; Qian, Q.K.; Lam, P.T.I. The market for green building in developed Asian cities-the perspectives of building designers. Energy Policy 2009, 37, 3061-3070. [CrossRef]

45. Yijun, Y.; Ronghui, X. FDI, Environmental Regulation and Green Total Factor Productivity Growth of China's Industry: An Empirical Study Based on Luenberger Index. J. Int. Trade 2015, 8, 84-93.

46. Lam, P.T.I.; Chan, E.H.W.; Poon, C.S. Factors affecting the implementation of green specifications in construction. J. Environ. Manag. 2010, 91, 654-661. [CrossRef] [PubMed]

47. Cao, F.; Ge, Y.; Wang, J.F. Optimal discretization for geographical detectors-based risk assessment. GIScience Remote Sens. 2013, 50, 78-92. [CrossRef]

48. Ei-Sharif, W.; Horowitz, M.J. Why financial promotions work: Leveraging energy efficiency value to promote superior products. Proc. ACEEE Summer Study Energy Effic. Build. 2000, 5, 557-567.

49. Al-Thani, S.K.; Skelhorn, C.P.; Amato, A.; Koc, M.; Al-Ghamdi, S.G. Smart Technology Impact on Neighborhood Form for a Sustainable Doha. Sustainability 2018, 10, 4764. [CrossRef]

50. Tokbolat, S.; Karaca, F.; Durdyev, S.; Nazipov, F.; Aidyngaliyev, I. Assessment of Green Practices in Residential Buildings: A Survey-Based Empirical Study of Residents in Kazakhstan. Sustainability 2018, 10, 4383. [CrossRef]

51. Liu, Z.; Chen, K.; Peh, L.; Tan, K.W. A feasibility study of Building Information Modeling for Green Mark New Non-Residential Building (NRB): 2015 analysis. Energy Procedia 2017, 143, 80-87. [CrossRef]

52. Yangjie, F.D. American Green Building Policies, Regulations and Evaluation System. Constr. Sci. Technol. 2011, 6, 56-57.

53. Zuo, J.; Zhao, Z.Y. Green building research-current status and future agenda: A review. Renew. Sustain. Energy Rev. 2014, 30, 271-281. [CrossRef]

54. Monfared, I.G.; Sharples, S. Occupants' perceptions and expectations of a green office building: A longitudinal case study. Archit. Sci. Rev. 2011, 54, 344-355. [CrossRef]

55. Li, M.; Wu, W.H.; Wu, G.D. Green Building Promotion Mechanism Based on Stakeholder Dynamic Game. J. Civ. Eng. Manag. 2017, 34, 20-26.

(C) 2020 by the authors. Licensee MDPI, Basel, Switzerland. This article is an open access article distributed under the terms and conditions of the Creative Commons Attribution (CC BY) license (http://creativecommons.org/licenses/by/4.0/). 